\title{
Reclassification of Amycolatopsis orientalis subsp. lurida Lechevalier et al. 1986 as Amycolatopsis lurida sp. nov., comb. nov.
}

\author{
Erko Stackebrandt, ${ }^{1}$ Reiner M. Kroppenstedt, ${ }^{1}$ Joachim Wink ${ }^{2}$ \\ and Peter Schumann ${ }^{1}$ \\ ${ }^{1}$ DSMZ - Deutsche Sammlung von Mikroorganismen und Zellkulturen GmbH, Mascheroder \\ Weg 1b, 38124 Braunschweig, Germany \\ ${ }^{2}$ Aventis Pharma Deutschland $\mathrm{GmbH}$, Drug Innovation and Approval, Natural Products, \\ 65926 Frankfurt, Germany
}

Correspondence

Erko Stackebrandt erko@dsmz.de

\begin{abstract}
Amycolatopsis orientalis subsp. lurida DSM $43134^{\top}$ differs significantly from the type strain of A. orientalis, $A$. orientalis subsp. orientalis DSM $40040^{\top}$, and from other species of the genus in genomic and metabolic properties. Its elevation to species status as Amycolatopsis lurida sp. nov., comb. nov. is justified.
\end{abstract}

As indicated in the original description (Lechevalier et al., 1986), Amycolatopsis orientalis subsp. lurida differs from A. orientalis subsp. orientalis in only four of the 29 characteristics that were used originally by Gordon et al. (1978) to describe several Nocardia species. Of these, Nocardia orientalis was reclassified by Lechevalier et al. (1986) as A. orientalis. Moreover, genomic distinctness of the two subspecies was also noted, as the type strains shared only $46 \%$ DNA-DNA similarity as measured by the spectrophotometric method of Seidler \& Mandel (1971). As the metabolic properties of $A$. orientalis subsp. lurida matched the description of the species A. orientalis (Gordon et al., 1978), A. orientalis and A. orientalis subsp. lurida were created, rather than two separate species. Although not included in the original description, the subspecies name A. orientalis subsp. orientalis (Pittenger \& Brigham 1956) Lechevalier et al. 1986 was created automatically by the valid publication of A. orientalis subsp. lurida (ex Grundy et al. 1957) Lechevalier et al. 1986 (Rule 40d, Lapage et al., 1992).

In the course of the description of Amycolatopsis decaplanina (Wink et al., 2004), the type strains of the two subspecies of $A$. orientalis were included as reference strains in the analysis of genomic and metabolic properties. Similarity of the two almost-complete 16S rRNA gene sequences was $99.6 \%$ (GenBank accession nos: A. orientalis subsp. orientalis IMSNU $20058^{\mathrm{T}}$, AJ400711; A. orientalis subsp. lurida DSM $43134^{\mathrm{T}}$, AJ577997). The two subspecies were not phylogenetic neighbours, with strain IMSNU $20058^{\mathrm{T}}$ branching adjacent to Amycolatopsis japonica DSM $44213^{\mathrm{T}}$. RiboPrint patterns of the two type strains, determined with the restriction enzyme $P v u I I$, were distinctly different (Wink et al., 2004). Determination of DNA-DNA similarity by using the method of De Ley et al. (1970) and Huß et al.
(1983) at $69^{\circ} \mathrm{C}$ in $2 \times$ SSC that contained $10 \%$ DMSO gave a similarity value of $45 \cdot 2 \%$ (mean of $42 \cdot 3$ and $49 \cdot 1 \%$ ), which was virtually identical to the value of $46 \%$ that was determined by Lechevalier et al. (1986). Analysis of metabolic properties included determination of the utilization of carbohydrates on ISP 9 medium (Shirling \& Gottlieb, 1966) by using a 12-well microtitre plate technique. A fingerprint of enzymic activities was obtained by using API 20E and API ZYM test strips (Wink et al., 2004). Comparison of data obtained from both strains confirmed most of the results of Lechevalier et al. (1986), including utilization of arabinose, fructose, glucose, inositol, mannitol and xylose, indicating that application of different tests performed at different times gives reliable results. Utilization of rhamnose and sucrose cannot be evaluated, as test results were combined for several strains of $A$. orientalis subsp. orientalis and for the type strain of A. orientalis subsp. lurida. The data of Lechevalier et al. (1986) and those obtained in this study partially complement each other, resulting in the identification of 14 properties in which the type strains of the two subspecies differ (Table 1).

On the basis of genomic and metabolic differences, we propose to elevate the subspecies A. orientalis subsp. lurida to species rank under the name Amycolatopsis lurida sp. nov., comb. nov., following Rule 50a (Lapage et al., 1992). As a consequence of this step, A. orientalis subsp. orientalis loses its status as a subspecies.

\section{Description of Amycolatopsis lurida (Lechevalier, Prauser, Labeda \& Ruan 1986) sp. nov., comb. nov.}

Amycolatopsis lurida (lu'ri.da. L. fem. adj. lurida pale yellow, sallow). 
Table 1. Utilization of carbohydrates and enzymic activities of strains DSM $40040^{\top}$ and DSM $43134^{\top}$

Strains: 1 , A. orientalis DSM $40040^{\mathrm{T}} ; 2$, A. lurida DSM $43134^{\mathrm{T}}$.

\begin{tabular}{|lcc|}
\hline Substrate/activity & $\mathbf{1}$ & $\mathbf{2}$ \\
\hline Phosphatase $^{\star}$ & + & - \\
Growth in lysozyme broth $^{*}$ & - & + \\
Acid from: & & \\
$\quad$ Melibiose & + & - \\
$\quad$ Rhamnose & + & - \\
Inositol & + & - \\
Esterase (C4) & + & - \\
Lipase (C14) & + & + \\
Leucine arylamidase & - & + \\
Trypsin & - & + \\
$\beta$-Galactosidase & - & + \\
$\alpha$-Glucosidase & - & + \\
$\beta$-Glucosidase & - & + \\
Arginine dihydrolase & - & - \\
Urease & + & + \\
\hline
\end{tabular}

*According to Lechevalier et al. (1986). Other data are from Wink et al. (2004).

Basonym: Amycolatopsis orientalis subsp. lurida (ex Grundy et al. 1957) Lechevalier et al. 1986.

The description is based on that for A. orientalis and A. orientalis subsp. lurida (Lechevalier et al., 1986), supplemented with data from Wink et al. (2004). White aerial mycelium produces cylindrical, occasionally ovoid conidia in straight to flexuous chains. Spore surface is smooth. Vegetative mycelium branches frequently and appears to zigzag slightly. Yellow on ISP medium 2 and beige on ISP media 3-7. Melanoid pigment is not produced. Growth occurs at $10{ }^{\circ} \mathrm{C}$, but not at $45^{\circ} \mathrm{C}$. Arabinose, citrate, fructose, glucose and mannitol are utilized; raffinose, rhamnose, sucrose and xylose are not. Decomposes casein, hypoxanthine, tyrosine and xanthine; negative for adenine. Decarboxylation of citrate occurs, but is negative for benzoate and mucate. Produces nitrate reductase, urease, aesculinase, gelatinase, esterase lipase (C8), alkaline phosphatase, $N$-acetyl- $\beta$-glucosamidase, chymotrypsin phosphatase, acid and acetoin; negative for amylase, $\alpha$-galactosidase, $\alpha$-fucosidase, $\alpha$-mannosidase, $\beta$-glucuronidase, lysine decarboxylase, ornithine decarboxylase, tryptophan deaminase, indole production, cystine arylamidase and valine aryamidase. $\mathrm{H}_{2} \mathrm{~S}$ production is negative. Acid is produced from adonitol, arabinose, cellobiose, dextrin, erythritol, galactose, inositol, lactose, maltose, mannitol, methyl $\alpha$-Dglucoside, salicin, sucrose, trehalose and xylose; no acid is produced from raffinose or sorbitol. DNA G $+\mathrm{C}$ content is $67 \mathrm{~mol} \%$. Additional properties are given in Table 1. Producer of the glycopeptide antibiotic ristocetin, which is active against Gram-positive bacteria and mycobacteria.

Type strain is NRRL $2430^{\mathrm{T}}\left(=\mathrm{DSM} 43134^{\mathrm{T}}\right)$. Isolated from soil.

\section{References}

De Ley, J., Cattoir, H. \& Reynaerts, A. (1970). The quantitative measurement of DNA hybridization from renaturation rates. Eur J Biochem 12, 133-142.

Gordon, R. E., Mishra, S. K. \& Barnett, D. A. (1978). Some bits and pieces of the genus Nocardia: N. carnea, N. vaccinii, N. transvalensis, N. orientalis and N. aerocolonigenes. J Gen Microbiol 109, 69-78.

Grundy, W. E., Sinclair, A. C., Therriault, R. J., Goldstein, A. W., Ricker, C. J., Warren, H. B., Oliver, T. J. \& Sylvester, J. C. (1957). Ristocetin, microbiological properties. In Antibiotics Annual 19561957, pp. 687-698. New York: Medical Encyclopedia.

Huß, V. A. R., Festl, H. \& Schleifer, K.-H. (1983). Studies on the spectrophotometric determination of DNA hybridization from renaturation rates. Syst Appl Microbiol 4, 184-192.

Lapage, S. P., Sneath, P. H. A., Lessel, E. F., Skerman, V. B. D., Seeliger, H. P. R. \& Clark, W. A. (editors) (1992). International Code of Nomenclature of Bacteria (1990 Revision). Bacteriological Code. Washington, DC: American Society for Microbiology.

Lechevalier, M. P., Prauser, H., Labeda, D. P. \& Ruan, J.-S. (1986). Two new genera of nocardioform actinomycetes: Amycolata gen. nov. and Amycolatopsis gen. nov. Int J Syst Bacteriol 36, 29-37.

Pittenger, R. C. \& Brigham, R. B. (1956). Streptomyces orientalis, n. sp., the source of vancomycin. Antibiot Chemother 6, 642-647.

Seidler, R. J. \& Mandel, M. (1971). Quantitative aspects of deoxyribonucleic acid renaturation: base composition, state of chromosome replication, and polynucleotide homologies. $J$ Bacteriol 106, 608-614.

Shirling, E. B. \& Gottlieb, D. (1966). Methods for characterization of Streptomyces species. Int J Syst Bacteriol 16, 313-340.

Wink, J., Gandhi, J., Kroppenstedt, R. M., Seibert, G., Sträubler, B., Schumann, P. \& Stackebrandt, E. (2004). Amycolatopsis decaplanina sp. nov., a novel member of the genus with unusual morphology. Int J Syst Evol Microbiol 54, 235-239. 